\title{
Forfeiture Seizures and the Warrant Requirement
}

Property used in the commission of certain crimes is forfeited by statute to the government. ${ }^{1}$ Forfeitures may be either criminal or civil..$^{2}$ A criminal forfeiture is part of the punishment of a convicted individual. ${ }^{3}$ Seizure for forfeiture follows conviction. ${ }^{4}$ In contrast, civil forfeiture, with which this comment is concerned, is aimed at the "guilty" property itself." Seizure precedes a civil, in rem forfeiture trial. ${ }^{6}$

Most courts hold that a judicial warrant is not required for the

'See, e.g., 19 U.S.C. $\$ \S 1592-1624$ (1976) (forfeiture of smuggled goods and any vessel, plane, or vehicle used to facilitate the smuggling); 21 U.S.C. $\$ 881$ (1976) (forfeiture of controlled substances and the containers and conveyances thereof); 49 U.S.C. $\$ \S 781-789$ (1976) (forfeiture of vessels and vehicles used to transport or conceal any contraband, in particular drugs, firearms, and counterfeit money); I.R.C. $\$ \S 7302,7321$ (forfeiture of property used, or intended for use, in violation of the Internal Revenue Code; this section most frequently is applied to items associated with gambling, counterfeiting, or distilling).

The focus of this comment is on federal forfeitures. Because the fourth amendment applies to the states through the fourteenth amendment, however, Wolf v. California, 338 U.S. 25, 27-28 (1949), the argument extends to state forfeitures. The state statutes generally are patterned after their federal counterparts.

2 The distinction may be more theoretical than real. See Note, Bane of American Forfeiture Law-Banished at Last?, 62 CoRnell L. Rev. 768 (1977).

${ }^{3}$ Criminal forfeitures were abolished in this country in 1790 , see S. REP. No. 91-617, 91st Cong., Ist Sess. 79-80 (1969), but were reestablished in the Organized Crime Control Act of 1970 , which calls for the forfeiture of racketeering property owned by a defendant convicted under the Act. Pub. L. No. 91-452, 84 Stat. 437 (codified at 18 U.S.C. $\$ 1963$ (1976)). Section 408 of the Comprehensive Drug Abuse Prevention and Control Act of 1970, 21 U.S.C. $\$ 848$ (1976), also provides for criminal forfeiture.

4 The Federal Rules require that the indictment allege the full extent of the property subject to forfeiture, FED. R. CRIM. P. 7(c)(2), that the jury return a special verdict for forfeiture, id. 31(e), and that the judgment authorize the seizure of the forfeit property, id. 32(b)(2). These rules do not apply to civil forfeitures. Id. 54(b)(5); id. 7(c)(2), 1979 Advisory Comm. Notes.

B The Supreme Court has described the nature of the proceeding thus:

A forfeiture proceeding ... is in rem. It is the property which is proceeded against, and, by resort to a legal fiction, held guilty and condemned as though it were conscious instead of inanimate and insentient. In a criminal prosecution it is the wrongdoer in person who is proceeded against, convicted and punished. [Here t] feiture is no part of the punishment for the criminal offense.

Various Items of Personal Property v. United States, 282 U.S. 577, 581 (1931) (citations omitted).

- See text and notes at notes 17-28 infra. 
initial seizure of an article subject to civil forfeiture. ${ }^{7}$ This "forfeiture exception" to the fourth amendment's warrant requirement has not, however, been endorsed universally. ${ }^{8}$ After briefly describing forfeitures and the forfeiture exception, this comment evaluates the arguments for and against requiring a warrant for a forfeiture seizure. It concludes that the justifications for dispensing with the warrant are unsatisfactory and argues that property seized for forfeiture without a warrant should be returned to the owner.

\section{BACKGROUND}

\section{A. Forfeiture}

Forfeiture has been criticized as odious, harsh, and inflexible. ${ }^{9}$ Nevertheless, it has withstood both the test of time and repeated

United States v. Bush, 647 F.2d 357 (3d Cir. 1981); United States v. One 1975 Pontiac Lemans, 621 F.2d 444 (1st Cir. 1980); United States v. Milham, 590 F.2d 717 (8th Cir. 1979); United States v. White, 488 F.2d 563 (6th Cir. 1973); United States v. Stout, 434 F.2d 1264 (10th Cir. 1970); United States v. Francolino, 367 F.2d 1013 (2d Cir. 1966); Sanders v. United States, 201 F.2d 158 (5th Cir. 1953). The Supreme Court expressly refused to consider the issue in Calero-Toledo v. Pearson Yacht Leasing Co., 416 U.S. 663, 679.80 n.14 (1974), and other decisions of the Court cannot be read as authorizing the exception, see Note, The Forfeiture Exception to the Warrant Requirement: A Distinction Without a Difference, 67 VA. L. REv. 1035, 1038-41 (1981).

- A few courts have held that a warrant must be obtained. United States v. McCormick, 502 F.2d 281 (9th Cir. 1974); Melendez v. Shultz, 356 F. Supp. 1205 (D. Mass.) (three judge court), appeal dismissed for lack of jurisdiction, 486 F.2d 1032 (1st Cir. 1973); United States v. One 1949 Model Ford Coach Automobile, 101 F. Supp. 492 (W.D.S.C. 1951); Department of Natural Resources v. Seaman, 396 Mich. 299, 240 N.W.2d 206 (1976); Fuqua v. Armour, 543 S.W.2d 64 (Tenn. 1976). See also United States v. Walters, 647 F.2d 947, 951 (6th Cir. 1981) (action for forfeiture of firearms remanded for decision whether the seizure exceeded the scope of the warrant obtained); United States v. One 1975 Pontiac Lemans, 621 F.2d 444, 451-59 (1st Cir. 1980) (Coffin, C.J., dissenting); United States v. Pruett, 551 F.2d 1365, 1369-70 (5th Cir. 1977), rehearing denied, 569 F.2d 427 (5th Cir. 1978) (warrantless seizure in forfeiture situation held unconstitutional, although the forfeiture exception apparently was raised explicitly only on petition for rehearing); Interbartolo v. United States, 303 F.2d 34, 37-38 (1st Cir. 1962) (but for imposing precedent, court would require a warrant for forfeiture seizures in the absence of exigent circumstances); United States $v$. Thrower, 442 F. Supp. 272, 278 (E.D. Pa.) (warrantless search and seizure upheld under the automobile exception, but validity of such seizures under forfeiture statutes questioned), aff'd mem., 568 F.2d 771 (3d Cir. 1977); In re Forfeiture of 1972 Porsche, 307 So. 2d 451, 452-53 (Fla. Dist. Ct. App. 1975) (warrantless search and seizure for forfeiture illegal); $2 \mathrm{~W}$. LaFAve, Search and Seizure 550-52 (1978); Note, supra note 7.

- United States v. United States Coin \& Currency, 401 U.S. 715, 719-21 (1971); State v. 1971 Green GMC Van, 354 So. 2d 479, 484-85 (La. 1977). See also cases cited at note 115 infra; Finkelstein, The Goring Ox: Some Historical Perspectives on Deodands, Forfeitures, Wrongful Death and the Western Notion of Sovereignty, 46 TEMP. L.Q. 169, 252 (1973). 
constitutional challenges. ${ }^{10}$ The notion of the guilty chattel has been traced to the Book of Exodus, ${ }^{11}$ which dictates that a goring $o x$ is to be killed and left uneaten.12 In early modern England, forfeiture took the form of the deodand, by which the instrument of a person's death was forfeited to the Crown. ${ }^{13}$ In this country, early civil forfeitures occurred primarily in admiralty, ${ }^{14}$ and forfeiture provisions long have been included in the revenue laws. ${ }^{15}$ "[C]ontemporary federal and state forfeiture statutes reach virtually any type of property that might be used in the conduct of a criminal enterprise."

The modern statutory schemes call for the seizure of certain property which, because used illegally, is contraband forfeit to the government. ${ }^{17}$ Seizure brings the item within the jurisdiction of the

10 " '[W] hether the reason for [the forfeiture] be artificial or real, it is too firmly fixed in the remedial and punitive jurisprudence of this country to be now displaced.' CaleroToledo v. Pearson Yacht Leasing Co., 416 U.S. 663, 686 (1974) (quioting J.W. GoldsmithGrant Co. v. United States, 254 U.S. 505, 510-11 (1921)) (forfeiture not a denial of procedural due process despite absence of preseizure notice and opportunity for a hearing). See also One Lot Emerald Cut Stones \& One Ring v. United States, 409 U.S. 232 (1972) (forfeiture not a violation of the double jeopardy clause); Van Oster v. Kansas, 272 U.S. 465 (1926) (forfeiture of innocent owner's property not an unconstitutional taking).

1s See 1 W. Blackstone, Commentaries on the Laws of England 291 (Oxford 1765); Note, Rendering Illegal Behavior Unprofitable: Vehicle Forfeiture Under the Uniform Controlled Substances Act, 8 Creighton L. REv. 471, 472 (1974).

12 "When an ox gores a man or woman to death, the ox shall be stoned, and its flesh may not be eaten; the owner of the ox shall be free from liability." Exodus 21:28 (New English). The view that the Biblical rule is linked to modern forfeiture is challenged in Finkelstein, supra note 9, at 180-82.

1s See O.W. Holmes, The Common LaW 24-28 (1881) (tracing the development of forfeitures from the deodand); Finkelstein, supra note 9, at 250-51. See also $1 \mathrm{~W}$. BLACKsTonE, supra note 11, at 290-92. Although comfortable with forfeitures in their punitive form, Blackstone seemed troubled when the link between the owner of the forfeit property and the crime is attenuated, as when A runs B through with C's sword. Id. at 291. The deodand, which was never fully established in this country, was abolished in England in 1846. Note, supra note 11, at 473 .

.14 E.g., The Emily, 22 U.S. (9 Wheat.) 381 (1824) (forfeiture of vessel used in illegal slave trade); The Hoppet, 11 U.S. (7 Cranch.) 389 (1813) (forfeiture of vessel used to import goods illegally); La Vengeance, 3 U.S. (3 Dall.) 297 (1796) (forfeiture of vessel used to export arms and ammunition illegally).

${ }_{15}$ E.g., Act of July 13, 1866, ch. 184, $\S 23,14$ Stat. 151; Act of February 18, 1793, ch. 8, $\S \S 8,9,12,1$ Stat. 305 (current version at I.R.C. $\S \S 7302,7321$ ).

${ }_{16}$ Calero-Toledo v. Pearson Yacht Leasing Co., 416 U.S. 663, 683 (1974).

17 A distinction must be drawn between per se contraband and derivative contraband. Derivative contraband-for example, a car or money used criminally-is contraband only by virtue of its illegal use. There is nothing criminal in its possession as such. Per se contraband-for example, a narcotic substance-is contraband by definition; no property rights can exist therein, and its very possession is criminal. One 1958 Plymouth Sedan v. United States, 380 U.S. 693, 699 (1965); United States v. Farrell, 606 F.2d 1341, 1344 (D.C. Cir. 
court and prevents its destruction, sale, or concealment. ${ }^{18}$ After the seizure, the government is required to notify the owner, who must post bond if he wishes to claim the property. ${ }^{19}$ Although some courts have found the owner entitled to an immediate postseizure administrative hearing, ${ }^{20}$ this is not a statutory requirement. ${ }^{21}$

If a claimant appears, the government files an in rem civil suit for forfeiture of the property; the property itself is the named defendant. ${ }^{22}$ Because the property is technically forfeit on commission of the crime, the trial is characterized as an action to perfect the government's title. ${ }^{23}$ The statutes are largely silent as to the specific procedures to be followed at the trial. ${ }^{24}$ The government bears the initial burden of demonstrating the existence of probable cause for the seizure and forfeiture; the burden then shifts to the property's owner to establish that the property is not in fact forfeit. ${ }^{25}$ The inquiry focuses on whether the alleged crime occurred and, if so, the extent of the property's involvement in its commission. Neither the acquittal of the criminal defendant ${ }^{26}$ nor the ignorance or innocence of the owner ${ }^{27}$ are valid defenses. ${ }^{28}$ Although

1979). Forfeiture statutes do not forfeit per se contraband; they affect only property that otherwise would belong to its nominal owner-that is, derivative contraband. No warrant is necessary for the seizure of per se contraband because its possessor, by definition, has no protected interest therein. There is a strong public policy against leaving such contraband in private possession. Those cases requiring a warrant for forfeiture seizures are careful not to extend that requirement to per se contraband. See Melendez v. Shultz, 356 F. Supp. 1205, 1210 (D. Mass.), appeal dismissed for lack of jurisdiction, 486 F.2d 1032 (1st Cir. 1973). See also United States v. One 1975 Pontiac Lemans, 621 F.2d 444, 454 n.8 (1st Cir. 1980) (Coffin, C.J., dissenting).

18 Calero-Toledo v. Pearson Yacht Leasing Co., 416 U.S. 663, 679 (1974).

19 E.g., 19 U.S.C. $\$ \S 1607-1608$ (1976) (incorporated by reference in 21 U.S.C. $\$ 881$ (d) (1976)).

${ }^{20}$ See Ivers v. United States, 581 F.2d 1362, 1368 (9th Cir. 1978); Lee v. Thornton, 538 F.2d 27, 33 (2d Cir. 1976).

21 See generally Kandaras, Due Process and Federal Property Forfeiture Statutes: The Need for Immediate Post-Seizure Hearing, 34 Sw. L.J. 925 (1980).

22 If no claimant appears, the property is forfeited summarily. E.g., 19 U.S.C. $\$ 1609$ (1976). See text and note at note 143 infra.

${ }^{23}$ See United States v. Mills, 440 F.2d 647, 648 (6th Cir.), cert. denied, 404 U.S. 837 (1971).

24 But see 19 U.S.C. $\S 1615$ (1976). The Supplemental Rules of the Federal Rules of Civil Procedure govern so far as applicable. United States v. \$5,372.85 in United States Coin \& Currency, 283 F. Supp. 904, 906 (S.D.N.Y. 1968). Jury trial is available. 1 J. MoorE, Federal Practice II 0.62[15] (2d ed. 1980).

${ }^{25}$ See United States v. One 1971 Chevrolet Corvette, 496 F.2d 210, 212 (5th Cir. 1974).

${ }^{26}$ One Lot Emerald Cut Stones \& One Ring v. United States, 409 U.S. 232, 234-35 (1972) (per curiam).

${ }^{27}$ Calero-Toledo v. Pearson Yacht Leasing Co., 416 U.S. 663, 683-86 (1974). The rigidity of this rule may be easing somewhat. See Note, supra note 7, at 1049. 
most statutes allow for administrative clemency in particularly harsh cases, ${ }^{29}$ the courts are required to follow the letter of the statute. ${ }^{30}$

\section{B. The Forfeiture Exception}

Although warrantless searches and seizures usually violate the fourth amendment, ${ }^{31}$ the warrant requirement is not all-encompassing. No warrant is required for arrests, ${ }^{32}$ for seizures incident to arrest, ${ }^{33}$ when the subject consents to the search, ${ }^{34}$ for searches and seizures at international borders, ${ }^{35}$ and, under certain limited exceptions, for automobile searches ${ }^{36}$ Moreover, warrants are not required for the seizure of abandoned property ${ }^{37}$ or of evidence in

${ }^{28}$ See generally United States v. Four Pinball Machines, 429 F. Supp. 1002, 1006-07

(D. Hawaii 1977).

${ }^{29}$ E.g., 19 U.S.C. § 1618 (1976).

${ }^{30}$ E.g., United States v. One 1961 Cadillac, 337 F.2d 730, 733 (6th Cir. 1964); United States v. Andrade, 181 F.2d 42, 46 (9th Cir. 1950); United States v. One 1977 Chevrolet Pickup, 503 F. Supp. 1027, 1029, 1030 (D. Colo. 1980).

31 Katz v. United States, 389 U.S. 347, 357 (1967). The fourth amendment provides:

The right of the people to be secure in their persons, houses, papers, and effects, against unreasonable searches and seizures, shall not be violated, and no Warrants shall issue, but upon probable cause, supported by Oath or affirmation, and particularly describing the place to be searched, and the persons or things to be seized.

U.S. ConsT. amend. IV.

${ }^{32}$ United States v. Watson, 423 U.S. 411, 417-18 (1976).

${ }^{33}$ Chimel v. United States, 395 U.S. 752, 762-63 (1969).

${ }^{34}$ Schneckloth v. Bustamonte, 412 U.S. 218, 222 (1973).

$3 s$ United States v. Ramsey, 431 U.S. 606, 616-19 (1977).

${ }^{36}$ Under the so-called "automobile exception," a somewhat unclear and much debated concept first articulated in Carroll v. United States, 267 U.S. 132, 151, 155-56 (1925), a warrantless search and seizure of an automobile is valid when the enforcement agent has probable cause and there are exigent circumstances. See Moylan, The Automobile Exception: What It Is and What It Is Not-A Rationale In Search of A Clearer Label, 27 MERCER L. REv. 987 (1976); Note, Warrantless Searches and Seizures of Automobiles, 87 HaRv. L. REv. 835 (1974) [hereinafter cited as Harvard Note]; Note, Warrantless Searches and Seizures of Automobiles and the Supreme Court from Carroll to Cardwell: Inconsistently Through the Seamless Web, 53 N.C.L. Rev. 722 (1975). "Exigent circumstances" typically arise because the car is being driven away. E.g., Carroll v. United States, 267 U.S. 132, 13536 (1925); United States v. 1964 Ford Thunderbird, 445 F.2d 1064, 1067 (3d Cir. 1971), cert. denied, 405 U.S. 964 (1972).

Although the majority of forfeiture cases involve the seizure of automobiles, the forfeiture exception is distinct from the automobile exception. The latter doctrine posits a set of circumstances that makes a warrantless search and seizure reasonable and therefore not violative of the fourth amendment. South Dakota v. Opperman, 428 U.S. 364, 382 n.9 (1976) (Powell, J., concurring). In contrast, the forfeiture exception holds a warrantless seizure reasonable, even though no exigency exists, because the property is subject to different treatment by virtue of being forfeit.

${ }^{37}$ Abel v. United States, 362 U.S. 217, 241 (1960). 
"plain view"s8 or in the "open fields."s9 "Exigent circumstances" also may excuse the warrant requirement."

In addition, most courts recognize a "forfeiture exception" under which an agent may seize property without a warrant whenever he has probable cause to believe the property is forfeit to the government. ${ }^{41}$ Most forfeiture statutes make no reference to warrants. Although a number of courts have inferred congressional endorsement of warrantless seizure from this silence, ${ }^{42}$ the statutes are ambiguous, typically providing merely that property "shall be seized."43

sB Harris v. United States, 390 U.S. 234, 236 (1968).

30 Hester v. United States, 265 U.S. 57, 59 (1924).

10 Terry v. Ohio, 392 U.S. 1, 20 (1968); Ker v. California, 374 U.S. 23, 41.42 (1963); McDonald v. United States, 335 U.S. 451, 454-56 (1948); Johnson v. United States, 333 U.S. 10, 14-15 (1948).

"See note 7 supra.

12 United States v. Panebianco, 543 F.2d 447, 456 (2d Cir. 1976), cert. denied, 429 U.S. 1103 (1977); Drummond v. United States, 350 F.2d 983, 988 (8th Cir. 1965). See also United States v. Whitlock, 418 F. Supp. 138, 141 (E.D. Mich. 1976), aff'd mem., 566 F.2d 583 (7th Cir. 1977).

4s E.g., 19 U.S.C. $\S 1595$ a(a) (1976); 49 U.S.C. $\S 782$ (1976). Some statutes explicitly provide for the use of warrants. See 21 U.S.C. $\$ 334$ (b) (1976); 31 U.S.C. $\$ 1105$ (1976).

Two important forfeiture statutes, although vague, arguably require a warrant for seizure. The Internal Revenue Code directs that property used or intended for use in violation of the Code is forfeit and that a warrant for its seizure "may issue." I.R.C. § 7302. At the least, this language suggests that seizure pursuant to a warrant is the favored procedure, and the statute might be read to require a warrant when there are no exigent circumstances. The courts generally have not adopted this interpretation. See United States v. One 1975 Pontiac Lemans, 621 F.2d 444, 450 (1st Cir. 1980) ("[W]e find nothing in either this specific language or the statutory scheme as a whole that reflects any congressional intent to require a warrant for the execution of section 7302 seizures."). But see United States v. Jeffers, 342 U.S. 48, 52-54 (1951) (holding that the predecessor of section 7302 required a warrant and that the warrantless search of a hotel room and seizure of untaxed drugs were illegal); United States v. One Plymouth Coupe, 182 F.2d 180, 182 (3d Cir. 1950), overruled on other grounds, United States v. $\$ 1,058.00$ in United States Currency, 323 F.2d 211, 212-13 (3d Cir. 1963).

The Comprehensive Drug Abuse Prevention and Control Act of 1970 requires forfeiture of controlled substances and their containers and conveyances. 21 U.S.C. $\$ 881$ (1976). The statute provides for seizure "upon process issued pursuant to the Supplemental Rules for Certain Admiralty and Maritime Claims" except when the seizure is incident to arrest, the property already has been judged to be forfeit, the property is dangerous, or the Attorney General has probable cause to believe the property has been or will be used in violation of the Act. $I d$. $\$ 881$ (b). A literal reading of the final exception would seem to endorse the forfeiture exception, and it has been so read. United States v. Milham, 590 F.2d 717, 720 (8th Cir. 1979). However, if no warrant were required when the agent had probable cause, the provision for a warrant would have no meaning; thus read, the statute would never require a warrant. The exception therefore must be read more narrowly. Common sense, the nature of the first three exceptions, and comparison with the standard exceptions to the warrant requirement suggest that the fourth exception should be limited to situations in 
The forfeiture exception is illustrated in United States $v$. One 1975 Pontiac Lemans. ${ }^{4}$ Charles Zullo, a numbers runner using his wife's Pontiac to transport betting slips, had not paid the special wagering tax; ${ }^{45}$ the car therefore was property used and intended for use in violating the revenue laws and subject to forfeiture. ${ }^{48}$ Without a warrant, revenue agents seized Mrs. Zullo's car from a public street. No criminal proceedings against Zullo were initiated, nor did the Treasury Department attempt to recover the unpaid taxes. ${ }^{47}$ The district court upheld the warrantless seizure and declared the car forfeit; ${ }^{48}$ the First Circuit affirmed ${ }^{49}$ over the strong dissent of Chief Judge Coffin.

In contrast, the Ninth Circuit held in United States v. McCormick $k^{50}$ that a warrant is required for forfeiture seizures because no exception explicitly authorized by the Supreme Court applies. ${ }^{81}$ The court argued that Congress cannot legislate additional exceptions to the warrant requirement. ${ }^{82}$ To construe the statute in ac-

which there are exigent circumstances, which are likely to be associated with the sudden appearance of probable cause. This view was taken in United States v. Pappas, 613 F.2d 324 (1st Cir. 1979). The court construed the fourth exception to section 881(b) to mean that warrantless seizures may occur only immediately after probable cause arises, when exigencies preclude the procurement of a warrant. Nonetheless, it held that contraband discovered during a subsequent inventory search of an illegally seized automobile need not be excluded from the defendant's criminal trial. Id. at 330-31. See also O'Reilly v. United States, 486 F.2d 208, 213-15 (8th Cir.) (Lay, J., dissenting), cert. denied, 414 U.S. 1043 (1979). Contra, United States v. Bush, 647 F.2d 357, 367-68 (3d Cir. 1981); United States v. One 1977 Lincoln Mark V. Coupe, 643 F.2d 154, 157-58 (3d Cir. 1981).

Whether these statutes should be read to require a warrant for seizure absent exigent circumstances is complicated by disagreement about whether forfeiture statutes should be liberally or strictly construed. Compare United States v. Stowell, 133 U.S. 1, 12 (1890) and Note, supra note 11, at 478 (advocating a liberal construction) with United States v. One Assortment of 25 Firearms, 483 F. Supp. 16, 19 (E.D. Tenn. 1979) ("forfeitures are not favored and should not be enforced unless they are within the letter and spirit of the law"); Kane v. McDaniel, 407 F. Supp. 1239 (W.D. Ky. 1975); and 3 C. Sands, Statutes and STatUTORY Construction $\S 66.11$, at 214 (rev. 4th ed. 1974) ("those provisions in revenue acts which impose . . . forfeitures . . . are given the same strict construction ordinarily applied to penal laws").

14621 F.2d 444 (1st Cir. 1980).

45 This tax is required by I.R.C. $\S 4411$.

46 I.R.C. § 7302.

47 Joint Appendix, Stipulated Facts at 6, United States v. One 1975 Pontiac Lemans, 621 F.2d 444 (1st Cir. 1980).

4870 F. Supp. 1243, 1247 (D. Mass. 1979).

621 F.2d 444 (1st Cir. 1980).

so 502 F.2d 281 (9th Cir. 1974).

s1 Id. at $285 \cdot 89$.

s2 Id. at 285-86. McCormick relied largely on Almeida-Sanchez v. United States, 413 U.S. 266 (1973), which held that Congress cannot legislate in violation of the requirements of the fourth amendment. Id. at 272. McCormick read this holding as dictating that 
cordance with the presumption of constitutionality, the court implied a provision requiring a warrant except when a traditional basis for a warrantless seizure exists. ${ }^{.3}$

The McCormick rationale goes too far. The exceptions to the warrant requirement authorized by the Supreme Court are not comprehensive; they only are descriptive of specific circumstances in which a warrantless search or seizure is reasonable and therefore constitutional. Congress surely may identify similar circumstances, ${ }^{54}$ and its judgment deserves a certain deference. ${ }^{55}$ Thus, it is proper neither to allow the forfeiture exception because Congress has called for it, nor to disallow it because it is not identical to exceptions already articulated by the Supreme Court. An independent assessment of its constitutionality is required.

\section{RAtionales fOR THE Forfeiture ExCEPtion}

The rationales for the forfeiture exception include the ostensible shift of property rights in the seized item and the in rem nature of the forfeiture action. ${ }^{58}$ This section explores these rationales and concludes that neither supports dispensing with warrants for forfeiture seizures.

\section{A. Shifting Property Rights}

Many courts have justified the forfeiture exception by reasoning that the government needs no warrant to take what it already owns. ${ }^{57}$ These courts argue that because property rights in an

"[u]nless the statute itself falls within one of the exceptions to the warrant requirement, it must yield to the right to be secure against searches and seizures." 502 F.2d at 285 .

ss 502 F.2d at 288-89. The Ninth Circuit arguably has retreated from its original position but has distinguished rather than overruled McCormick. See United States v. Kimak, 624 F.2d 903, 905 (9th Cir. 1980), which upheld a warrantless forfeiture seizure when made on the spot of the crime and within the Carroll automobile exception, see note 36 supra.

st See United States v. Francolino, 367 F.2d 1013, 1022 (2d Cir. 1966) (Friendly, J.) ("We realize that upholding the validity of the statute as so construed [to allow warrantless forfeiture seizures] amounts to recognizing that Congress . . . may in effect create a further exception to the requirement of a search warrant. . . . Congress [has not] here exceeded its constitutional powers in dispensing with a search warrant.").

ss United States v. DiRe, 332 U.S. 581, 585 (1940).

so The underlying practical justification for the forfeiture exception is presumably its convenience; this assumes rather than argues for the constitutionality of warrantless seizures. Inconvenience never can be allowed to affect the evaluation of whether a warrant is required. McDonald v. United States, 335 U.S. 451, 454-55 (1948); Trupiano v. United States, 334 U.S. 699, 705-06 (1948); Johnson v. United States, 333 U.S. 10, 14-15 (1948).

${ }^{87}$ See United States v. One 1975 Pontiac Lemans, 621 F.2d 444, 450 (1st Cir. 1980); United States v. Pappas, 600 F.2d 300, 306 (1st Cir.) ("[A] property interest of this sort, 
offending article pass to the government on commission of the crime, ${ }^{58}$ the article therefore is contraband and, as such, is "not property the ownership or possession of which the law protects." The Supreme Court invited this property rights rationale in Boyd $v$. United States ${ }^{60}$ by distinguishing the seizure of private papers, for which it required a warrant, from seizure of forfeit or stolen goods. ${ }^{61}$

1. Privacy Expectations. Although the government's property rights sanction the forfeiture seizure, they have no bearing on how the seizure should be carried out. Focusing on property rights affected ignores critical privacy interests. ${ }^{62}$ Privacy concerns are implicated whenever a search must be conducted to discover the article to be seized. The status of the property seized has no bearing on the vitality of these privacy interests with respect to a search. ${ }^{63}$ Thus, even if the government's purported property rights

created by operation of law, places the agents of the government in a different position constitutionally vis-a-vis the forfeit vehicle than would otherwise be true."), vacated for rehearing en banc and decided on other grounds, 613 F.2d 324 (1st Cir. 1979); United States v. Zaicek, 519 F.2d 412, 414 (2d Cir. 1975); United States v. Troiano, 365 F.2d 416, 418 (3d Cir.), cert. denied, 385 U.S. 958 (1966); Sanders v. United States, 201 F.2d 158, 159 (5th Cir. 1953) ("The Fourth Amendment does not guarantee against seizures . . . [where] the right to the property has already passed to the United States by forfeiture.").

This rationale suggests that there is no seizure in the fourth amendment sense and therefore no need to evaluate reasonableness. Pushed to extremes, this fiction becomes absurd. E.g., United States v. One 1952 Victoria, 114 F. Supp. 458, 459 (N.D. Cal. 1953) ("[S]eizure occurs when the car is illegally used. The physical repossession of the automobile may occur subsequently.").

${ }^{58}$ United States v. Stowell, 133 U.S. 1, 16-17 (1890); Simons v. United States, 541 F.2d 1351, 1352 (9th Cir. 1976); Weathersbee v. United States, 263 F.2d 324, 326 (4th Cir. 1958); United States v. Pacific Finance Corp., 110 F.2d 732, 733 (2d Cir. 1940).

so United States v. Troiano, 365 F.2d 416, 418 (3d Cir.), cert. denied, 385 U.S. 958 (1966).

60 116 U.S. 616 (1886).

B1 Id. at 623 ("In the one case, the government is entitled to possession of the property, in the other it is not."). Although this language has carried great weight with courts permitting warrantless forfeiture seizures, see United States v. Francolino, 367 F.2d 1013, 1022 (2d Cir. 1966); Grogan v. United States, 261 F.2d 86, 87 (5th Cir. 1958), the Boyd reference to forfeit property is mere dictum. "What Mr. Justice Bradley said [in Boyd] about stolen or forfeited goods or contraband is, of course, not accurate if read to mean that they may be seized at any time even without a warrant or not incident to an arrest that is lawful." Warden v. Hayden, 387 U.S. 294, 318 (1967) (Douglas, J., dissenting).

62 Modern fourth amendment jurisprudence emphasizes privacy rather than property interests. See United States v. Salvucci, 448 U.S. 83, 91-92 (1980); Rakas v. Illinois, 439 U.S. 128, 143 (1978); Katz v. United States, 389 U.S. 347, 352-53 (1967); Warden v. Hayden, 387 U.S. 294, 304-05 (1967).

63 "It is settled doctrine that probable cause for belief that certain articles subject to seizure are in a dwelling cannot of itself justify a search without a warrant." Jones v. United States, 337 U.S. 493 , 497-98 (1958). 
justify a warrantless seizure, they cannot support a warrantless search ${ }^{64}$ Although no court explicitly has asserted to the contrary, reliance on the forfeiture exception has led to some careless decisions from which this result might be inferred. ${ }^{60}$ The forfeiture exception must not be used to justify otherwise unconstitutional warrantless searches. ${ }^{68}$

The usual forfeiture situation, seizure of an automobile from a public area or driveway, does not involve so obvious an intrusion on privacy. However, there is an expectation of privacy in an automobile, ${ }^{67}$ an expectation unavoidably intruded upon by the process of seizure. Moreover, the car almost certainly will be subject to a subsequent warrantless search. ${ }^{68}$ Thus, privacy interests are implicated even when no search for the article to be seized is necessary. Finally, even where individual interests do not fit squarely within the current jurisprudential "privacy" mold, seizure remains an intrusion. In an effort to protect property interests, some courts $^{69}$ and commentators ${ }^{70}$ have expanded notions of "privacy"

34 The law of arrest parallels the law of seizure in this respect. See Steagald v. United States, 101 S. Ct. 1642, 1648 (1981) (arrest warrant does not authorize search of third party's home for subject of warrant; arrest warrant goes to reasonableness of the seizure, but not of the search).

os E.g., Sanders v. United States, 201 F.2d 158 (5th Cir. 1953) (car seized on private premises); United States v. One Bally "Barrell-O-Fun," 224 F. Supp. 794 (M.D. Pa. 1963) (seizure of pinball machines from inside amusement hall), aff'd mem. sub nom. Brozettie v. Rogers, 337 F.2d 857 (3d Cir. 1964).

cs See also United States v. Jeffers, 342 U.S. 48 (1951), in which agents searched a hotel room and seized untaxed drugs that were forfeit under the predecessor to I.R.C. $\$ 7302$. The government argued that because under the statute no property rights existed in the property, the search and seizure without a warrant was valid. The Court rejected this contention, noting that "Congress, in abrogating property rights in such goods, merely intended to aid in their forfeiture" and not to affect the fourth amendment's requirements. Id. at 53-54.

67 Although the interior of an automobile is not granted the same status as the interior of a home, South Dakota v. Opperman, 428 U.S. 364, 379 (1976) (Powell, J., concurring); Cardwell v. Lewis, 417 U.S. 583, 590 (1974) (plurality opinion); Chambers v. Maroney, 399 U.S. 42, 52 (1970), significant privacy interests in automobiles do exist, United States v. Ortiz, 422 U.S. 891, 896 (1975). See also Coolidge v. New Hampshire, 403 U.S. 443, 461-62 (1971) ("The word 'automobile' is not a talisman in whose presence the Fourth Amendment fades away and disappears."). Even though the expectation of privacy in the interior of a car is minimal, that in the glove compartment or trunk is substantial. See Arkansas v. Sanders, 442 U.S. 753 (1979); Rakas v. Illinois, 439 U.S. 128, 148-49 (1978).

${ }^{8}$ See text and notes at notes 120-129 infra.

s. In State v. Sweatt, 427 A.2d 940, 945-46 (Me. 1981), the court found unconstitutional the seizure of gems pursuant to a warrant inadequately describing the items to be seized, even though the gems were on display at a jeweler's. Although the invitation of public scrutiny indicated the absence of any expectation of privacy in the usual sense, the majority labeled the seizure an invasion of privacy. See also Lo-Ji Sales, Inc. v. New York, 442 U.S. 319,329 (1979) (legitimate expectation of privacy despite display of items to the general 
beyond their logical boundaries. Such a semantic sleight-of-hand correctly recognizes the inherent intrusiveness of seizure; it would be more honest, however, to acknowledge the fourth amendment's protection of proprietary interests. ${ }^{\text {71 }}$

It might be argued, however, that when property rights shift to the government because of the illegal use of an article, there is a concomitant abandonment of privacy expectations. If an owner wrote out a deed transferring property to the United States, the government presumably would not be required to obtain a warrant to take the property, because the owner would have abandoned all his rights of property and privacy. In a sense, illegal use of the property is the equivalent of such a transfer. Although the owner might still object to the actual seizure, the transfer is nonetheless voluntary in that the crime was volitional and knowledge of the forfeiture statute must be presumed. The fourth amendment protects only "legitimate" expectations of privacy; ;2 $^{72}$ having forfeited the property by his own criminal actions, the owner retains no such interest.

Even if the forfeiture is seen as effecting such a voluntary transfer, however, ${ }^{78}$ the deed situation is distinguishable for three reasons. First, in the forfeiture case the claimant may have been unaware of the illegal activity. It is difficult to believe that parents no longer have a legitimate expectation of privacy in the family car because their son drove it with marijuana in his pocket. Second, most property that theoretically is subject to forfeiture is never proceeded against. The owner of such property retains, or at least eventually regains, a legitimate privacy interest in the property. Finally, even if the technical transfer of ownership is sufficient to destroy privacy expectations, a warrant serves the important function of ensuring that such a transfer in fact has occurred.

2. The Ex Post Nature of the Property Rights Rationale.

public).

${ }^{70}$ See Note, supra note 7, at 1046 ("a privacy interest may also be defined as encompassing the individual's interest in controlling material goods owned by him") (footnote omitted).

"The fourth amendment requires a warrant to describe not only "the place to be searched, [but also] the persons or things to be seized." See note 31 supra. See also United States v. One 1975 Pontiac Lemans, 621 F.2d 444, 455 (1st Cir. 1980) (Coffin, C.J., dissenting); State v. Sweatt, 427 A.2d 940, 951-52 (Me. 1981) (Carter, J., concurring) (although there was no expectation of privacy, seizure violated a proprietary interest).

72 Rakas v. Illinois, 439 U.S. 128,143 n.12 (1978).

${ }^{73}$ For the view that forfeiture works an involuntary transfer and that privacy expectations remain, see Harvard Note, supra note 36 , at 847-48. 
The property rights rationale, grounded on factual assumptions not proven at the time of the seizure, is illogical. ${ }^{74}$ It is a basic tenet of fourth amendment jurisprudence that searches and seizures cannot be justified ex post. ${ }^{78}$ It would be more logical to argue that the probability that the property is forfeit gives the government a sufficient interest to seize it without a warrant. Yet a warrant is required in part because probable interests fall short of absolute rights. To consider the property already forfeit for the purpose of seizure is to overlook the very essence of the warrant requirement-to have an impartial judicial officer assess the situation before allowing the enforcement agent to proceed..$^{78}$

3. The G.M. Leasing Case. The foregoing privacy/property distinctions are necessary to understand the Supreme Court's decision in G.M. Leasing Corp. v. United States, ${ }^{77}$ which has been cited in support of the forfeiture exception. ${ }^{78}$ In G.M. Leasing, the Internal Revenue Service seized several cars from the plaintiff corporation, which was the alter ego of a delinquent taxpayer against whom the IRS had made a jeopardy assessment. The seizures were made from public places without a warrant. Addressing the automobile seizures in a single perfunctory paragraph, the Court found no constitutional violation. ${ }^{70}$ The G.M. Leasing seizures closely resemble the typical forfeiture situation, and at first blush the case seems to indicate that a warrant is not required for forfeiture

24 Courts have rejected similar attempts by the government to impose substantive consequences stemming from the theoretical shift in property rights prior to an actual judicial determination. See Rogers v. United States, 47 Am. Fed. TAx REp. 2D (P-H) 81-690 (D. Minn. 1980); United States v. $\$ 22,993.00$ in Currency, 332 F. Supp. 1277 (E.D. La. 1971) (both rejecting the argument that because title passed on commission of the crime, the former owner had at best a claim to seized currency and therefore, under the Assignment of Claims Act, 31 U.S.C. § 203 (1976), could not assign his interest in the property).

${ }^{73}$ For example, in Michigan v. Tyler, 436 U.S. 499 (1978), the state attempted to justify a warrantless search of a building on a theory of abandonment by arson. There was no dispute that abandoned premises can be searched and that arson constitutes abandonment. The search was not permitted, however, because "it is . . . impossible to justify a warrantless search on the ground of abandonment by arson when that arson has not yet been proved." Id. at 505-06. See also Henry v. United States, 361 U.S. 98, 104 (1959); United States v. DiRe, 332 U.S. 581, 595 (1948).

76 See text and notes at notes 108-119 infra.

77429 U.S. 338 (1977).

78 See United States v. Bush, 647 F.2d 357, 369 (3d Cir. 1981); United States v. One 1975 Pontiac Lemans, 621 F.2d 444, 450 (1st Cir. 1980); United States v. Pappas, 600 F.2d 300,304 (1st Cir.), vacated for rehearing en banc and decided on other grounds, 613 F.2d 324 (1st Cir. 1979).

79429 U.S. at 351-52. The Court went on to find the warrantless seizure of the corporation's papers from its offices unconstitutional. Id. at 352-59. 
seizures-at least of automobiles on public streets.

Important distinctions, however, cut against such a reading. ${ }^{80}$ There was no question in G.M. Leasing that the taxpayer owed taxes and that the IRS could seize his property to satisfy that debt. ${ }^{81}$ Moreover, the privacy interests of the individual taxpayer and the corporation were minimal at best. The expectation of privacy in a corporation's car used for customer rental is less than that in a personal car, the seizures were not followed by a police search, and the seizures did not occur on property belonging either to the corporation or the taxpayer. ${ }^{82}$ In addition, because the taxpayer had notice of the impending seizure,$^{83}$ he had time to protect his privacy interest. Finally, it can be argued that in a tax levy case there are no privacy interests anywhere in the car because all items, including those in the trunk or glove compartment, are also part of the levy and belong to the IRS. In the typical forfeiture situation, in contrast, the government has rights only to the automobile, not to items therein.

G.M. Leasing should be read only as authorizing a warrantless seizure where there is a complete absence of both property and privacy interests. In relying on G.M. Leasing to justify the forfeiture exception, however, the First Circuit viewed the decision as combining reduced property and privacy interests to justify warrantless seizures. ${ }^{84}$ To so read G.M. Leasing is to attempt to add

so Strong arguments also can be made that G.M. Leasing was wrongly decided. See 2 W. LAFAve, supra note 8, at 552-53; Rosenthal, Jeopardy and Termination Assessments After Laing and Hall: Jeopardizing the Fourth Amendment, 31 TAx L. REv. 317, 351-54 (1976) (arguing, before G.M. Leasing, that a warrant should be required for jeopardy assessment seizures).

81 Tax assessments are "given the force of a judgment." Bull v. United States, 295 U.S. 247, 260 (1935). The government's property right was equally indisputable in the cases relied on by the Court in G.M. Leasing. In Murray's Lessee v. Hoboken Land \& Improvement Co., 59 U.S. (18 How.) 272 (1856), seizure to satisfy a debt to the United States was made pursuant to a "warrant of distress," an administrative warrant issued by the Solicitor of the Treasury. As the Court felt obliged to point out, a warrant of distress is "conclusive evidence of the facts recited in it, and of the authority to make the levy." Id. at 285. In Hester v. United States, 265 U.S. 57 (1924), federal agents seized distilled liquor in an open field. No property rights existed in the liquor because it was per se contraband, and in any case it had been abandoned. Id. at 58-59. In contrast to the forfeiture situation, these cases did not require a magistrate's judgment to determine the probability that the property belonged to the government.

82429 U.S. at 344.

${ }^{83}$ IRS agents had visited the taxpayer's home seeking payment and had filed notice of tax liens with the county recorder's office. Id. at 342-43.

84 United States v. Pappas, 600 F.2d 300, 304 (1st Cir.) ("While the [G.M. Leasing] - Court's analysis was conclusory, it was evidently based upon the owner's reduced expecta- 
apples and oranges. Property and privacy interests are independent factors, each deserving of the protection of a warrant, and the partial absence of both should not be combined synergistically to eliminate the necessity of a warrant for forfeiture seizures.

\section{B. The In Rem Nature of the Civil Forfeiture Action}

Civil forfeiture always has been viewed as a remedial proceeding directed solely against an offending object. ${ }^{85} \mathrm{It}$ is independent of any action against a criminal defendant ${ }^{88}$ and may go forward

tion of privacy and the government's claim of a property right . . . ."), vacated for rehearing en banc and decided on other grounds, 613 F.2d 324 (1st Cir. 1979). The Pappas court applied this combinative approach to forfeiture seizures: "where the car owner's expectation of privacy is least . . . and the government's interest most basic-i.e., a statutory property right-a warrantless seizure could generally be sustained." $600 \mathrm{~F} .2 \mathrm{~d}$ at 305 .

s5 Ames v. Kansas, 111 U.S. 449, 460-61 (1884); The Palmyra, 25 U.S. (12 Wheat.) 1, 14 (1827). A number of nonpunitive justifications have been suggested: forfeiture repays society for the damage done by the crime and the cost of investigation, United States v. 86.9 Cases, More or Less of Assorted Distilled Spirits, Wine and Beer, 337 F. Supp. 1355, 1356 (S.D. Fla. 1971); it removes the tools of the criminal trade, United States v. Jenison, 484 F. Supp. 747, 753 (D.R.I. 1980); United States v. One 1976 Lincoln Mark IV, 462 F. Supp. 1383, 1391 (W.D. Pa. 1979); and it discourages criminal behavior by decreasing its profitability, H.R. REP. No. 2751, 81st Cong., 2d Sess. (1950), reprinted in [1950] U.S. CoDE Cong. \& AD. News 2952.

There remains a built-in tension in the very concept of a civil, remedial forfeiture. When the owner is innocent, the justifications for forfeiture seem insufficient; the natural inclination is to search for an underlying punitive link and object if one cannot be found. Arguably, the many disputes surrounding civil forfeitures stem from this inherent tension. See note 43 supra, concerning the debate over the strictness with which forfeiture statutes should be construed. Courts and commentators have struggled with the criminal overtones of forfeiture. See Calero-Toledo v. Pearson Yacht Leasing Co., 416 U.S. 663, 683-89 (1974) (emphasizing that forfeitures are civil and that the owner's innocence is no defense); United States v. United States Coin \& Currency, 401 U.S. 715, 719-22 (1971) (emphasizing the punitive elements of forfeiture and suggesting that the innocence of the owner might block forfeiture); Boyd v. United States, 116 U.S. 616, 634 (1886) (labeling forfeitures "quasi-criminal"); United States v. One 1970 Pontiac GTO, 529 F.2d 65, 66 (9th Cir. 1976) (forfeitures are criminal for fourth and fifth amendment purposes, but "not criminal enough" to prevent placing the burden of proof on the claimant). The continued vitality of this confusion is demonstrated by a recent Sixth Circuit case regarding gamblers' fifth amendment rights in defending an action for forfeiture of gambling profits. United States v. United States Currency, 626 F.2d 11 (6th Cir. 1980). In his concurring opinion, Judge Merritt took the majority to task for treating forfeiture "as a kind of hybrid which is neither fish nor fowl" and argued that forfeiture should be characterized as a purely criminal proceeding. Id. at 18. See generally Charney, The Need for Constitutional Protections for Defendants in Civil Penalty Cases, 59 Cornelr L. Rev. 478 (1974); Clark, Civil and Criminal Penalties and Forfeitures: A Framework for Constitutional Analysis, 60 MinN. L. REv. 379, 475-81 (1976); Note, supra note 2 , at $783-85,800-02$.

so Neither the conviction nor the acquittal of the criminal defendant, who may or may not be the owner of the property, has any res judicata or collateral estoppel effect on the forfeiture. One Lot Emerald Cut Stones \& One Ring v. United States, 409 U.S. 232, 234-35 
even if criminal charges are never brought. ${ }^{87}$ Thus, it is arguable that forfeiture falls entirely within the civil ambit, where constitutional protections are traditionally less stringent than in criminal proceedings $^{88}$ and where the fourth amendment's warrant requirement is not always strictly applied. ${ }^{89}$ It is fallacious, however, to equate a forfeiture seizure with a simple civil attachment. The action is a form of punishment, ${ }^{90}$ frequently used as a substitute for criminal prosecution. ${ }^{91}$ The Supreme Court has made it clear that these criminal overtones necessitate observance of the fourth amendment. $^{92}$ Although that amendment requires only that seizures be reasonable, a warrant, which usually is necessary to ensure reasonableness, cannot be avoided simply because the action is "civil." As As one court has written, the Supreme Court's forfei-

(1972).

87 This was the case, for example, in United States v. One 1975 Pontiac Lemans, 621 F.2d 444 (1st Cir. 1980); see Joint Appendix, Stipulated Facts at 6.

ss See Charney, supra note 85 , at 480 .

89 See Founding Church of Scientology v. United States, 409 F.2d 1146, 1150 (D.C. Cir.), cert. denied, 396 U.S. 963 (1969). Even in the civil context some process is required, however. "[T]he Fourth Amendment does . . . apply to such seizures, in both its substantive prohibition against unreasonable seizures and its procedural requirement of judicial or quasi-judicial review of the decision to seize." Id. See also Supp. Rules to Fed. R. Crv. P. for Certain Admiralty \& Maritime Claims $B(1), C(2), C(3)$ (issuance of a warrant for seizure on the basis of verified complaint, sworn affidavit, and description of item to be seized). Cf. United States v. Pappas, 613 F.2d 324, 328-29 (1st Cir. 1979) (probable cause requirement applies to warrants issued under Supplemental Rule C); United States v. Articles of Hazardous Substance, 588 F.2d 39, 43 (4th Cir. 1978) (finding fourth amendment's probable cause requirement satisfied by the Supplemental Rules procedure).

${ }^{20}$ See United States v. United States Coin \& Currency, 401 U.S. 715, 721-22 (1971) ("When the forfeiture statutes are viewed in their entirety, it is manifest that they are intended to impose a penalty only upon those who are significantly involved in a criminal enterprise."); United States v. One 1976 Lincoln Mark IV, 462 F. Supp. 1383 (W.D. Pa. 1979) (finding a trend supporting a constitutional prohibition against forfeiture of property of innocent owner who acted reasonably under the circumstances).

91 See One 1958 Plymouth Sedan v. Pennsylvania, 380 U.S. 693, 701 (1965). Forfeiture frequently serves the same ends as criminal prosecution more effectively and efficiently. If forfeiture rules are drawn too loosely, "the Government, by electing to proceed against suspects via the forfeiture route, could deprive citizens of the constitutionally-mandated safeguards which surround the criminal process." United States v. One 1972 Datsun, 378 F. Supp. 1200, 1206 (D.N.H. 1974).

${ }^{92}$ One 1958 Plymouth Sedan v. Pennsylvania, 380 U.S. 693, 700-02 (1965) (extending the exclusionary rule to forfeiture proceedings); Boyd v. United States, 116 U.S. 616, 634 (1886) ("As, therefore, suits for penalties and forfeitures incurred by the commission of offences against the law, are of this quasi-criminal nature, we think that they are within the reason of criminal proceedings for all the purposes of the Fourth Amendment of the Constitution ....").

93 Moore concedes that "there may be constitutional limitations on the power to use maritime seizure procedures [for in rem actions] to enforce government forfeiture or penal 
ture opinions indicate "that the civil nature of forfeiture proceedings will not be permitted to provide an avenue through which the fundamental rights of protection against unreasonable searches and seizures and self-incrimination can be frustrated."94 Although the Court has been unwilling to provide forfeiture claimants with the whole gamut of constitutional protections enjoyed by criminal defendants, ${ }^{95}$ it has stressed the criminal aspects of the proceeding when invoking fourth and fifth amendment protections. ${ }^{96}$

A related argument dismissing the need for warrants is that forfeiture is in rem "and does not, in any degree, touch upon the person of the offender."97 The rights of concerned individuals generally are seen as ancillary at best; the entire structure of forfeiture deemphasizes owners' rights. ${ }^{98}$ Notably, an owner's innocence is no defense to forfeiture. ${ }^{92}$ This rule, upheld in some exceedingly harsh cases, ${ }^{100}$ is justified on the ground that the action is solely in

statutes . . . ."7A J. Moore, supra note 24, $\pi$ C.11. Even those procedures offer some of the protection provided by a magistrate's warrant. See note 89 supra.

*4 Bramble v. Richardson, 498 F.2d 968, 973 (10th Cir.), cert. denied, 419 U.S. 1069 (1974).

95 See generally Charney, supra note 85 , at $483-91$ (cataloguing "criminal" constitutional protections and discussing their applicability to "civil" cases).

96 Compare United States v. United States Coin \& Currency, 401 U.S. 715, 718 (1971) and One 1958 Plymouth Sedan v. Pennsylvania, 380 U.S. 693, 700-01 (1965) (emphasizing the quasi-criminal nature of forfeiture in extending fourth and fifth amendment protections thereto) with Calero-Toledo v. Pearson Yacht Leasing Co., 416 U.S. 663, 680-90 (1974) (forfeiture of innocent owner's property is not a deprivation of property without just compensation in violation of the fifth amendment, because forfeiture is not criminal and serves purposes beyond punishment) and One Lot Emerald Cut Stones \& One Ring v. United States, 409 U.S. 232, 235-36 (1972) (civil versus criminal distinction relied on to avoid fifth amendment's double jeopardy prohibition).

97 La Vengeance, 3 U.S. (3 Dall.) 297, 301 (1796).

- For an extreme example of the tendency to ignore personal rights by donning in rem blinders, see People ex rel. Hanrahan v. One 1965 Oldsmobile, 52 Ill. 2d 37, 45-46, 284 N.E.2d 646, 652, rev'd sub nom. Robinson v. Hanrahan, 409 U.S. 38 (1972). In that case, a car belonging to an incarcerated robbery suspect was seized pursuant to an Illinois automobile forfeiture statute. The suspect never received notice of the impending forfeiture because it was sent to his home rather than to the prison. The car was forfeited summarily when, not surprisingly, he failed to claim it. The Illinois Supreme Court held the service sufficient because the action was in rem; the Supreme Court reversed on due process grounds.

9 Calero-Toledo v. Pearson Yacht Leasing Co., 416 U.S. 663, 684-88 (1974); The Palmyra, 25 U.S. (12 Wheat.) 1, 14-15 (1827).

${ }_{100}$ See, e.g., Calero-Toledo v. Pearson Yacht Leasing Co., 416 U.S. 663 (1974) (yacht belonging to lessor forfeited when lessee brought marijuana aboard, entirely unknown to lessor); United States v. One 1969 Plymouth Fury Automobile, 509 F.2d 1324 (5th Cir.) (new car forfeited when purchaser, who had put only $\$ 100$ down, used it to commit a crime; innocent seller forfeited the remaining value of the car), cert. denied, 423 U.S. 838 (1975); United States v. One 1957 Oldsmobile, 256 F.2d 931 (5th Cir. 1958) (trial court had found 
rem. ${ }^{101}$ The in rem premise, however, "is a deliberate subterfuge-a judicial fiction."102 The government's treatment of property cannot be distinguished from its treatment of the people associated with the property. As the Supreme Court has said in a related context, "[p]roperty does not have rights. People have rights. The right to enjoy property without unlawful deprivation, no less than the right to speak or the right to travel, is in truth a 'personal' right ....."10s

It is striking that the criminal defendant is so well protected against the illegitimate seizure of his property, ${ }^{104}$ while the owner of property subject to civil forfeiture, who may well be unconnected to any crime, is entirely unprotected. ${ }^{105}$ If in the former situation a final judgment must authorize the seizure, it would seem reasonable that in the latter a warrant should be required. ${ }^{108}$ That property is not taken as part of a criminal action against its owner does not diminish the need for fourth amendment protection. ${ }^{107}$

forfeiture "unconscionable").

${ }^{101}$ See, e.g., United States v. Twenty-Eight "Mighty Payloader" Coin-Operated Gaming Devices, 623 F.2d 510, 516 (8th Cir. 1980) ("[T]he innocence of the owner is not a defense to forfeiture, since the proceeding is in rem against the article to be forfeited.").

${ }^{102}$ Finkelstein, supra note 9, at 252. See also note 85 supra.

${ }^{105}$ Lynch v. Household Finance Corp., 405 U.S. 538, 552 (1972) (upholding federal jurisdiction under 28 U.S.C. $\$ 1343$ (3) (1976) of a challenge to a state prejudgment garnishment statute, against the objection that the section protected only "personal" rights).

106 See note 4 supra.

${ }^{105}$ See Camara v. Municipal Court, 387 U.S. 523, 530 (1967) (noting in the context of administrative searches that "[i]t is surely anomalous to say that the individual and his private property are fully protected by the Fourth Amendment only when the individual is suspected of criminal behavior").

${ }^{100}$ A more obvious, but perhaps unworkable, lesson offered by the criminal forfeiture process is that the entire forfeiture proceeding should precede seizure in civil cases as well. This proposal answers in the most effective way the objections to a warrantless seizure. It may seem that if preseizure notice and hearing are not required, Calero-Toledo v. Pearson Yacht Leasing Co., 416 U.S. 663, 679-80 (1974), preseizure forfeiture must be dismissed a fortiori. The Court's arguments in Pearson, however, are not altogether compelling in this context. Further, unlike preseizure notice and hearing, requiring a final forfeiture decree before seizure does not demand additional time or effort; it only alters the sequence of existing procedures. As noted in Pearson, however, $i d$. at 679 , there is a real possibility that the owner will transfer, conceal, or ruin the property before seizure. In a theoretical sense this is remedied easily by holding the owner liable for any decrease in the value of the property (down to zero) after the beginning of the action. But such a solution is not practically reassuring: it adds complications, may prove wasteful, and may not give the government its due if the orner is unable to pay a judgment.

${ }^{107}$ That the property itself is the accused suggests a compelling but overlooked analogy to the arrest of human suspects. See United States v. Bush, 647 F.2d 357, 369 (3d Cir. 1981). Warrantless arrests long have been sanctioned, though arrests pursuant to a warrant are preferred. United States v. Watson, 423 U.S. 411, 417-24 (1976). A forfeiture seizure is simply the arrest of property; the forfeiture exception may be described as the arrest rule ap- 


\section{The Safeguards of the Warrant}

Part II argued that the rationales for the forfeiture exception to the warrant requirement are seriously flawed. This part continues the analysis by focusing on the important functions served by a warrant. In particular, the warrant ensures neutral evaluation of probable cause for seizure, prevents the circumvention of the warrant requirement for searches, and protects due process in addition to fourth amendment interests.

\section{A. The Role of the Magistrate}

Whenever possible, a neutral magistrate, rather than the agent "engaged in the often competitive enterprise of ferreting out crime," should assess the government's right to search and seize. ${ }^{108}$ In the absence of a forfeiture statute or an established exception to the warrant requirement, property involved in the commission of a crime can be seized only with a warrant. ${ }^{109}$

When a seizure is based on the alleged involvement of property in a crime, a magistrate's independent preliminary assessment of the extent of that involvement is equally vital. Evaluating whether property may be forfeit "often depends on the making of delicate judgments about previous facts and circumstances,"110 judgments "squarely within the intended role of the magistrate under the fourth amendment." 111 The frequency with which the existence of probable cause has been questioned at trial ${ }^{112}$ demon-

plied to things. Such an application is not necessarily appropriate, however, because of the presence in the arrest situation of immediate postseizure procedures, bail, a greater need for flexibility, and the severe consequences of letting the "suspect" slip away. Moreover, the historical distinction between search and seizure of people and that of things argues against direct application. See id. at 429 (Powell, J., concurring). But see Payton v. New York, 445 U.S. 573, 589-90 (1980) (because the search for a person is just as intrusive as the search for property, a search warrant is required for an arrest in the home just as one is required for seizure of property therein).

108 Johnson v. United States, 333 U.S. 10, 14 (1948).

109 FED. R. CRIM. P. 41(b)(3) designates as property that may be seized with a warrant "property designed or intended for use or which is or has been used as the means of committing a criminal offense." Cf. Preston v. United States, 376 U.S. 364 (1964) (warrantless search and seizure of car carrying contraband held unconstitutional because it did not fall within any of the recognized warrant exceptions).

${ }_{110}$ Melendez v. Shultz, 356 F. Supp. 1205, 1210-11 (D. Mass. 1973).

111 United States v. One 1975 Pontiac Lemans, 621 F.2d 444, 464 (1st Cir. 1980) (Coffin, C.J., dissenting). See also 2 W. LAFAve, supra note 8, at 551.

112 In the forfeiture proceeding the initial burden is on the government to show probable cause for the seizure and forfeiture. E.g., United States v. One 1971 Chevrolet Corvette, 496 F.2d 210, 212 (5th Cir. 1974); 19 U.S.C. $\$ 1605$ (1976) (incorporated by reference in 21 
strates that the status of the property often is far from clear. ${ }^{113}$ This uncertainty is particularly acute in the forfeiture situation because the evaluation is not simply factual (was there a crime and what was the involvement of this property?) but also legal (on these facts, is the property subject to forfeiture?). Forfeiture often is denied because of the absence of a sufficient nexus between the property and the crime. ${ }^{114}$ The assessment of probable cause for seizure is a precursor to a judicial determination and therefore is best made by a judicial officer.

That the protection of a warrant should be considered unnecessary is particularly surprising in light of the consensus that forfeiture is harsh and disfavored.115 Every precaution should be taken to guard against unnecessary seizures. ${ }^{116}$ Because final deter-

U.S.C. $\S 881$ (1976)). Probable cause is something more than mere suspicion and must be reasonable under the circumstances, Bush v. United States, 389 F.2d 485, 489 (5th Cir. 1968), but falls short of a prima facie case. United States v. One 1975 Ford Pickup Truck, 558 F.2d 755, 756 (5th Cir. 1977); Ted's Motors v. United States, 217 F.2d 777, 780 (8th Cir. 1954). In short, the government's asserted right to the property is established by "the same standard employed to test searches and seizures generally." United States v. One $1975 \mathrm{Mer}-$ cedes 280 S, 590 F.2d 196, 199 (6th Cir. 1978). It should be noted that because of this congruence, requiring a warrant does not increase the government's evidentiary burden.

${ }^{113}$ For examples of seizures made without or with only questionable probable cause, see United States v. One Twin Engine Beech Airplane, 533 F.2d 1106 (9th Cir. 1976) (reversing district court, which had found no probable cause); United States v. LaVecchia, 513 F.2d 1210 (2d Cir. 1975) (probable cause unclear); United States v. One 1971 Chevrolet Corvette, 496 F.2d 210 (5th Cir. 1974) (government failed to show probable cause); Howard v. United States, 423 F.2d 1102 (9th Cir. 1970) (no evidence of probable cause); Compton v. United States, 377 F.2d 408 (8th Cir. 1967) (overruling trial court's judgment non obstante veredicto for forfeiture); United States v. One 1967 Cessna Aircraft, 454 F. Supp. 1352 (C.D. Cal. 1978); United States v. One 1973 Lincoln Continental Mark IV, 391 F. Supp. 1197 (N.D. Cal. 1975); United States v. One 1972 Datsun, 378 F. Supp. 1200 (D.N.H. 1974). See also note 119 infra.

114 See, e.g., Howard v. United States, 423 F.2d 1102, 1103-04 (9th Cir. 1970); United States v. One 1972 Datsun, 378 F. Supp. 1200, 1206 (D.N.H. 1974); Suhomlin v. United States, 345 F. Supp. 650, 654-55 (D. Md. 1972); United States v. 1,922 Assorted Firearms \& 229,553 Rounds of Assorted Ammunition, 330 F. Supp. 635, 642 (E.D. Mo. 1971).

118 United States v. One 1936 Model Ford V8 Deluxe Coach, 307 U.S. 219, 226 (1939); United States v. One 1977 Cadillac, 644 F.2d 500, 501 (5th Cir. 1981); United States v. One 1975 Mercedes 280S, 590 F.2d 196, 198 (6th Cir. 1978); Howard v. Federal Crop Ins. Corp., 540 F.2d 695, 697 (4th Cir. 1976); United States v. One 1976 Cadillac Seville, 477 F. Supp. 879, 882 (E.D. Mich. 1979); United States v. One 1965 Cadillac 2-Door Coupe, 260 F. Supp. 761, 762 (W.D. Pa. 1966).

116 The courts may be taken to task for a cavalier approach to unfounded seizures. See, e.g., United States v. One 1975 Pontiac Lemans, 621 F.2d 444, 450 (1st Cir. 1980) ("We see no insult to personal liberty, or threat to property, arising from the present state of the law . . . ."). Two decades earlier, the First Circuit had a somewhat different attitude:

Requiring . . . warrants . . . would more closely accord with our traditional concepts of subjecting official seizure of property to some kind of judicial scrutiny. The alternative 
mination of the property's status involves lengthy delay, ${ }^{117}$ seizure, particularly of an automobile, ${ }^{118}$ is likely to be a substantial and costly imposition even if the property ultimately isreturned. Finally, there is a danger of harassment and abuse if seizures are not judicially supervised. ${ }^{119}$

\section{B. Postseizure Searches}

\section{In Cooper v. California, ${ }^{120}$ the Supreme Court upheld the war-}

to this, under the situation as presently obtains, permits government agents to summarily sweep automobiles off the streets without any legal process so long as at one time, however remote, those officials believe that the vehicle was used in furtherance of an illicit or proscribed activity. The ipse dixit of the officer or the agent is all that is required. However, since infallibility or omniscience is scarcely expected, the official may well be wrong . . . .

Interbartolo v. United States, 303 F.2d 34, 37 (1st Cir. 1962).

${ }_{112}$ In cases of official bad faith, the period may be exceptionally long. E.g., United States v. One 1972 Wood 19 Foot Custom Boat, 501 F.2d 1327 (5th Cir. 1974) (ten months); Mayo v. United States, 413 F. Supp. 160 (E.D. III. 1976) (claimant filed for return of the property after the government had held it for over two years); United States v. One 1970 Buick Riviera, 374 F. Supp. 277 (D. Minn. 1973) (twenty months). Even when the case apparently is pursued with reasonable diligence the property is likely to remain in the government's hands for several months. E.g., Cooper v. California, 386 U.S. 358 (1967) (four months between seizure and forfeiture proceeding); United States v. One 1976 Cadillac Seville, 477 F. Supp. 879 (E.D. Mich. 1979) (three months); United States v. One Assortment of 93 Firearms, 463 F. Supp. 365 (D.S.C. 1978) (two and one half months). Excessive delays have been held unconstitutional in some cases on due process grounds. $E$.g., United States v. $\$ 8,850.00$ in United States Currency, 645 F.2d 836 (9th Cir. 1981) (eighteen months); United States v. One Ford Pickup, 564 F.2d 864 (9th Cir. 1977) (eleven months); Sarkisian v. United States, 472 F.2d 468 (10th Cir.) (nine months from completion of investigation to filing of suit), cert. denied, 414 U.S. 976 (1973); United States v. Eight Rhodesian Stone Statues, 449 F. Supp. 193 (C.D. Cal. 1978) (sixteen months); United States v. One 1971 Opel G.T., 360 F. Supp. 638 (C.D. Cal. 1973) (thirteen and one-half months).

The danger of property being seized and held for months without any judicial or official consideration is mitigated somewhat by cases, still the exception rather than the rule, requiring prompt postseizure administrative proceedings. See United States v. Thirty-Seven Photographs, 402 U.S. 363, 367-75 (1971); Ivers v. United States, 581 F.2d 1362, 1368 (9th Cir. 1978); Lee v. Thornton, 538 F.2d 27, 33 (2d Cir. 1976) (requiring immediate hearings in the border seizure situation, where the inconveniences are likely to be especially harsh). See also Kandaras, supra note 21, at 932-35 (arguing for automatic and comprehensive postseizure hearings). Although immediate postseizure review would guard against the inequities inherent in any seizure situation, it by no means would render warrants superfluous. The warrant requirement would still help prevent unnecessary seizures in the first place.

118 The Supreme Court emphasized the daily importance of the automobile in Bell v. Burson, 402 U.S. 535, 539 (1971).

119 For cases in which the power to seize has been abused, see United States v. One Buick Riviera, 374 F. Supp. 277 (D. Minn. 1973); United States v. One 1965 Cadillac 2-Door Coupe, 260 F. Supp. 761 (W.D. Pa. 1966); Boling v. Division of Narcotic Control of the Dep't of Pub. Safety, 24 Ill. 2d 305, 181 N.E.2d 147 (1962).

120386 U.S. 58 (1967). 
rantless search of an automobile seized and held for a state forfeiture proceeding. The car belonged to a criminal defendant, and the evidence discovered in the search was used in obtaining his conviction. ${ }^{121}$

The circuits generally have read Cooper as propounding an across-the-board rule that vehicles seized pursuant to a forfeiture statute may be searched without a warrant, ${ }^{122}$ effectively extending the forfeiture exception to automobile searches as well as to seizures. Agents thus may seize a car without a warrant on the basis of probable cause to believe it is forfeit and then search it, although the warrantless search would not otherwise have been legal. ${ }^{123}$ Some courts have held a prior seizure is not even neces-

121 Id. at 58. Because the seizure in Cooper was without a warrant, some courts have interpreted the case as endorsing warrantless forfeiture seizures. United States v. Pappas, 600 F.2d 300, 303-05 (1st Cir.), vacated for rehearing en banc and decided on other grounds, 613 F.2d 324 (1st Cir. 1979); United States v. Ortega, 471 F.2d 1350, 1360 (2d Cir. 1972). This view is unfounded. As Chief Judge Coffin has noted, Cooper conceded the legality of the seizure, and the question was not before the Court. United States v. One 1975 Pontiac Lemans, 621 F.2d 444, 452 (1st Cir. 1980) (Coffin, C.J., dissenting). It also appears that the seizure could have been justified as incident to arrest, for the statute directed the arresting officer to seize the vehicle. Cooper v. California, 386 U.S. 58, 60 (1967). The Court's own subsequent gloss on the decision is ambiguous: "The case stands for the proposition that, given an unquestionably legal seizure, there are special circumstances that may validate a subsequent warrantless search." Coolidge v. New Hampshire, 403 U.S. 443, 464 n.21 (1971). It seems, however, that the "unquestionably legal" language was not intended to provide a ringing endorsement to the forfeiture exception, but to emphasize that the search is only as good as the seizure upon which it is based. See South Dakota v. Opperman, 428 U.S. 364, 368-69 (1976); Chambers v. Maroney, 399 U.S. 42, 49-52 (1970).

${ }_{122}$ See United States v. Milham, 590 F.2d 717, 720 (8th Cir. 1979); United States v. McCormick, 502 F.2d 281, 284 (9th Cir. 1974); United States v. White, 488 F.2d 563, 564 (6th Cir. 1973); United States v. Mills, 440 F.2d 647 (6th Cir.), cert. denied, 404 U.S. 837 (1971). But see United States v. Johnson, 572 F.2d 227, 231-33 (9th Cir.) (suggesting that Cooper may be limited to inventory, and not investigatory, searches), cert. denied, 437 U.S. 907 (1978).

${ }^{123}$ In a pre-Cooper opinion, Chief Judge Murrah of the Tenth Circuit spoke out strongly against this anomaly:

The effect of this decision is to hold that the officers may seize without a warrant for probable cause that which they could not search for probable cause. And, having seized, they may then search for and seize contraband. I have found no authority to sanction this circumvention of the constitutional mandate which safeguards the citizen against unreasonable searches by requiring judicial authority in the form of a search warrant, except under circumstances which precludes [sic] its timely issuance. If this decision is now to be the law of search and seizure, officers need no longer trouble themselves to secure a search warrant for the seizure of a vehicle, be it standing or moving, for, all they need to do is to decide for themselves whether there is probable cause to believe that it is being used to violate the federal law.

Sirimarco v. United States, 315 F.2d 699, 703 (10th Cir. 1963) (dissenting to denial of petition for rehearing). 
sary. ${ }^{124}$ This anomaly suggests that to avoid outright circumvention of the fourth amendment, a warrant must be required for the initial seizure.

One could object to this argument on the ground that a seizure warrant is an inadequate substitute for a search warrant. A search warrant issues on probable cause to believe the search will uncover contraband or evidence, while a warrant for seizure issues on probable cause to believe the property is forfeit. Because of this incongruity, a warrant for the seizure does not necessarily protect against searches for which a warrant might not otherwise issue.

A seizure warrant provides equivalent protection, however, because it addresses the three factors Cooper relied on to legitimate the search. First, Cooper noted that the seizure, custody, and search of the car were all bound up with the crime that had been committed. ${ }^{125}$ Presumably the Court considered this relevant to the question of probable cause; the connection with the crime suggested that the search would be fruitful. Second, by emphasizing that the police were required to hold the car for an indefinite length of time, ${ }^{128}$ the Court suggested that the search was grounded on a possessory interest. ${ }^{127}$ Finally, the search was a rea-

124 United States v. Panebianco, 543 F.2d 447, 456 (2d Cir.) ("Where federal agents have probable cause to believe a vehicle is seizable . . . they may search it without a warrant, regardless of whether the vehicle has first been seized . . . ."), cert. denied, 429 U.S. 1103 (1976); United States v. LaVecchia, 513 F.2d 1210, 1216 (2d Cir. 1975); United States v. Ortega, 471 F.2d 1350, 1360 (2d Cir. 1972) (search of an automobile while it was cargo in the hold of a ship upheld in part on the ground that a car subject to forfeiture may be searched without a warrant), cert. denied, 411 U.S. 948 (1973). These decisions probably are inconsistent with Cooper, which was grounded largely on the fact of police custody. See Dyke v. Taylor Implement Mfg. Co., 391 U.S. 216, 220-21 (1968). The approach is consistent with Cooper to the extent that Cooper is based on the possessory interest the forfeiture statute creates rather than on the need for self-protection. See note 127 infra.

125386 U.S. at 61.

128 Id.

${ }^{127}$ Subsequent analyses of Cooper have found this implied possessory interest to be the critical factor supporting the decision. See South Dakota v. Opperman, 428 U.S. 364, 377 n.2 (1976) (Powell, J., concurring) ("In Cooper the Court validated [the] . . . search . . . on the theory that the police had a possessory interest in the car based on a state forfeiture statute . . . ."); Cady v. Dombrowski, 413 U.S. 433, 453 (1973) (Brennan, J., dissenting) ("[T]he police [in Cooper] were authorized to treat the car in their custody as if it were their own, and the search was sustainable as an integral part of their right of retention."); United States v. Jamerson, 549 F.2d 1263, 1270-71 (9th Cir. 1977). See also Dutile, Some Observations on the Supreme Court's Uses of Property Concepts in Resolving Fourth Amendment Problems, 21 CATH. U.L. REv. 1, 17-19 (1971); Harvard Note, supra note 36, at 847 (both concluding that the Cooper decision was based on the authorities' possessory interest). In Preston v. United States, 376 U.S. 364 (1964), a factually similar case except for the absence of a forfeiture statute, the warrantless search was held invalid. This suggests that the pos- 
sonable precautionary measure of police self-protection. ${ }^{128}$ This factor is premised on the legitimacy of possession by the police: if they were not entitled to have the car, no justification for the search based on possession would be tenable. ${ }^{129}$

A seizure warrant goes to each of these justifications. It ensures that the crime, the seizure, and the custody are all of a piece; it reflects the magistrate's evaluation that the government has a probable possessory interest under the forfeiture statute; and it ensures that the seizure is proper. A seizure warrant is therefore the functional equivalent of, and a necessary substitute for, a search warrant when automobiles are seized pursuant to a forfeiture statute.

\section{Due Process}

Two arguments in favor of requiring a warrant for forfeiture seizures are grounded on due process rather than fourth amendment concerns. The first is drawn from cases dealing with notice and hearing requirements and the second from the threat of summary forfeiture.

In Fuentes $v$. Shevin, ${ }^{130}$ the Supreme Court set rigid standards for preseizure notice and opportunity for a hearing, noting, however, that in the criminal context notice and hearing are unnecessary prior to a seizure pursuant to a warrant. ${ }^{131}$ Two years later, in Calero-Toledo v. Pearson Yacht Leasing Co., ${ }^{132}$ the Court held that forfeiture seizure "is one of those " "extraordinary situations" that justify [sic] postponing notice and opportunity for a hearing" " until after seizure. ${ }^{138}$ This holding places great confidence in the official assessment of the appropriateness of seizure, suggesting

sessory interest is critical; Cooper and Preston cannot be distinguished on any other ground. But see South Dakota v. Opperman, 428 U.S. 364, 373-74 n.8 (1976) (ultimate forfeiture was not a foregone conclusion in Cooper; "[n]o reason would therefore appear to limit Cooper to an impoundment pursuant to a forfeiture statute").

${ }^{128} 386$ U.S. at 61-62. See also South Dakota v. Opperman, 423 U.S. 364, 369 (1976); Cady v. Dombrowski, 413 U.S. 433, 447 (1973) (both citing Cooper for the proposition that a warrantless search is justified when necessary for self-protection).

${ }^{128}$ The search is only as valid as the seizure on which it is based. See Coolidge v. New Hampshire, 403 U.S. 443, $464 \mathrm{n} .21$ (1971) (search in Cooper valid because subsequent to "an unquestionably legal seizure"). In the same way, searches and seizures incident to arrest are valid only if the arrest is valid. Henry v. United States, 361 U.S. 98, 102 (1959).

130407 U.S. 67 (1972).

131 Id. at 93 n.30.

132416 U.S. 663 (1974).

${ }^{133}$ Id. at 677 (quoting Fuentes v. Shevin, 407 U.S. 67, 90 (1972)). 
that the assessment is made best through the warrant procedure. ${ }^{134}$

In approving prehearing seizures, the Court has emphasized the importance of judicial safeguards. In Mitchell v. W.T. Grant Co., ${ }^{135}$ the Court upheld Louisiana's sequestration procedure, which did not provide for preseizure notice and hearing, because of its other protections: a writ for the seizure based on the creditor's affidavit and issued by a judge, the availability of a bond procedure, and the opportunity for an immediate postseizure hearing. ${ }^{136}$ The following year, in North Georgia Finishing, Inc. v. Di-Chem, Inc. ${ }^{137}$ the Court struck down a Georgia garnishment statute that put the property "totally beyond use during the pendency of the litigation on the alleged debt, all by a writ of garnishment issued by a court clerk . . . without participation by a judicial officer."138 The Court distinguished Mitchell on the ground that the Louisiana procedure required judicial issuance of the writ on a factual rather than on a "conclusory" basis. ${ }^{139}$

Read together, these cases underscore the importance of judicially issued process for seizure when there is no prior notice or hearing. ${ }^{140}$ The exceptions to this rule, involving situations of public necessity, ${ }^{141}$ excuse rather than undercut the warrant requirement. Because under Pearson notice and hearing are not required prior to a forfeiture seizure, the inference is compelling that a warrant is. ${ }^{142}$

${ }^{134}$ Pearson was careful to note, however, that the warrant question was not before it. 416 U.S. at $679-80$ n.14.

13s 416 U.S. 600 (1974).

136 Id. at 607-10. The Court required that a valid seizure scheme balance the creditor's fear of waste or concealment of the property and the danger of violent self-help measures against the debtor's right to protection from wrongful deprivation. The same concerns are present in the forfeiture situation. See, e.g., Calero-Toledo v. Pearson Yacht Leasing Co., 416 U.S. 663,679 (1974).

237419 U.S. 601 (1975).

1so Id. at 606 . The quoted language would condemn, for the same reasons, a forfeiture scheme that allowed warrantless seizures.

130 Id. at 607.

140 See Johnson v. American Credit Co., 581 F.2d 526, 534 (5th Cir. 1978) ("It seems clear, then, that due process requires that a prejudgment seizure be authorized by a judge who has discretion to deny issuance of the appropriate writ."). But see Jonnet v. Dollar Sav. Bank, 530 F.2d 1123, 1130 n.15 (3d Cir. 1976) (these cases "might be read to require that a judge approve the seizure" but do "not necessarily establish judicial participation as a constitutional requisite").

141 See, e.g., Ewing v. Mytinger \& Casselberry, Inc., 339 U.S. 594 (1950) (seizure of misbranded drugs); North Am. Cold Storage Co. v. Chicago, 211 U.S. 306 (1908) (seizure of food unfit for human consumption).

${ }^{142}$ A more abstract analysis reaches the same conclusion. Fuentes suggested three fac- 
A second due process problem arises from the threat of summary forfeiture, which occurs if no one claims the seized property and posts the requisite penal bond. ${ }^{143}$ The legitimacy of summary forfeiture rests on the accuracy and reliability of the initial judgment that the property is subject to forfeiture. A warrantless seizure followed by summary forfeiture is forfeiture without any process at all. It is difficult to believe that none is due. A minimum level of judicial scrutiny, in the form of the issuance of a warrant for the seizure, would provide appropriate protection.

\section{Treatment of Property Seized Without a Warrant}

\section{A. Evidentiary Use}

One 1958 Plymouth Sedan v. Pennsylvania ${ }^{144}$ extended the exclusionary rule to forfeiture proceedings. Thus, property seized without a warrant under circumstances requiring one should be inadmissible as evidence in the forfeiture proceeding. ${ }^{145}$ Evidence obtained by a warrantless search subsequent to an illegal seizure also should be inadmissible. ${ }^{146}$

Moreover, the exclusionary rule also requires that property

tors that justify dispensing with preseizure notice and hearing, 407 U.S. at $91,93 \mathrm{n} .30$, factors echoed in Pearson, 416 U.S. at 679: seizure serves important governmental purposes, there is a need for prompt action, and other safeguards at least partially serve the function of notice and hearing.

Fuentes requires a balancing of the public interest and the urgency of the situation against the individual interests implicated. In an emergency situation, seizure without any judicial procedures would be tolerated; where the public necessity drops below a certain threshold, however, preseizure notice and opportunity for a hearing are required. The normal search and seizure situation lies somewhere between these two extremes. In Fuentes the Court noted that the magistrate's issuance of a warrant for the seizure of personal possessions was sufficient protection in the criminal context. 407 U.S. at 93 n.30. The government's interest in forfeiture is no greater and the circumstances no more pressing than in the typical warrant situation. Therefore, the protective procedure should be no less than the issuance of a warrant by a magistrate. Cf. Mathews v. Eldridge, 424 U.S. 319, 334-35 (1976) (referring to a similar set of factors with regard to due process requirements and focusing on, but not limiting its discussion to, the need for a hearing).

${ }^{143}$ See 19 U.S.C. $\$ \S 1607-1609$ (1976); 21 U.S.C. $\$ 881$ (d) (1976); I.R.C. $\S 7325$. In a decision that apparently has been ignored by the other circuits, the Ninth Circuit held the bond requirement in 19 U.S.C. $\$ 1608$ unconstitutional as a violation of both due process and equal protection. Wiren v. Eide, 542 F.2d 757, 763 (9th Cir. 1976). The constitutionality of section 3724 of the Internal Revenue Code of 1939 (present section 7325) was upheld against a due process challenge in Colacicco v. United States, 143 F.2d 410 (2d Cir. 1944).

${ }^{144} 380$ U.S. 693,702 (1965).

$145 \mathrm{Id}$. at 702.

${ }_{1 \ll 8}$ See Wong Sun v. United States, 371 U.S. 471, 485 (1963); United States v. One 1973 Lincoln Continental Mark IV, 391 F. Supp. 1197, 1200 (N.D. Cal. 1975). 
seized in violation of the warrant requirement be excluded in criminal proceedings against an individual defendant. ${ }^{147}$ When the defendant is the owner of the property, he has standing to object to the seizure. If the defendant has no possessory interest in the property, however, the exclusionary rule may not apply: because his fourth amendment rights were not violated by the warrantless seizure, he lacks standing to invoke the rule. ${ }^{148}$

\section{B. Forfeiture of Property Seized Without a Warrant}

1. Illegal Seizure as a Bar to Forfeiture. If the seized property cannot be introduced at the forfeiture trial, the government may have a difficult time proving that it had probable cause for the seizure. ${ }^{149}$ To this extent the exclusionary rule operates as a de facto bar against forfeiture of illegally seized property.

Defects in the seizure also should limit the government's underlying right to the property itself. A number of courts have held that forfeiture cannot follow an invalid seizure. ${ }^{150}$ Two early

147 Weeks v. United States, 232 U.S. 383, 393-94 (1914).

148 See Rakas v. Illinois, 439 U.S. 128, 133-34 (1978); Alderman v. United States, 394 U.S. 165, 174-76 (1969). The forfeiture situation is the clearest example of the link between property rights and standing to invoke the exclusionary rule objected to by the dissent in Rakas. 439 U.S. at 156 (White, J., dissenting). Justice Rehnquist recognized this in his opinion for the Court in United States v. Salvucci, 448 U.S. 83, 91 n. 6 (1980). See also State v. Sweatt, 427 A.2d 940, 951-52 (Me. 1981) (Carter, J., concurring).

149 See, e.g., United States v. One 1973 Lincoln Continental Mark IV, 391 F. Supp. 1197 (N.D. Cal. 1975); People v. Mota, 27 Ill. App. 3d 982, 327 N.E.2d 419 (1975).

${ }^{150}$ Berkowitz v. United States, 340 F.2d 168, 171 (1st Cir. 1965); Doherty v. United States, 500 F.2d 540, 547 (Ct. Cl. 1974); State v. 1971 Green GMC Van, 354 So. 2d 479, 48586 (La. 1977). Berkowitz was overruled implicitly by United States v. One 1975 Pontiac Lemans, 621 F.2d 444, 451 (1st Cir. 1980). Cf. Castleberry v. Alcohol, Tobacco, \& Firearms Div. of the Treasury Dep't, 530 F.2d 672, 675 (5th Cir. 1976) (refusing to consider plaintiff's motion for return of allegedly illegally seized automobile because "the proper place to litigate the legality of the seizure . . . is in the forfeiture proceedings"). A number of older circuit cases, subsequently overruled, held that forfeiture could not follow an illegal seizure. See United States v. Plymouth Coupe, 182 F.2d 180 (3d Cir. 1950); United States v. Specified Quantities of Intoxicating Liquors, 7 F.2d 835 (2d Cir. 1925); United States v. Loomis, 297 F. 359 (9th Cir. 1924). A form for pleading illegal seizure as a defense in a forfeiture action, with wording based on Berkowitz v. United States, 340 F.2d 168 (1st Cir. 1965), is found in 11 Am. Jur. Pr. \& Pr. Forms (Rev.) Fed. Tax Enf. Form 6 (1970).

See also Colonnade Catering Corp. v. United States, 397 U.S. 72 (1970), where IRS agents seized untaxed liquor after breaking and entering without a search warrant. Both the majority and dissenting Justices agreed that if the seizure were lawful, the liquor would be forfeit. The majority, finding the search and seizure illegal, ordered the liquor returned, $i d$. at 77; the dissenters objected that the search and seizure were valid and the liquor therefore was subject to forfeiture, id. at 78 (Burger, C.J., dissenting), 81 (Black, J., dissenting). 
Supreme Court cases ${ }^{151}$ and the weight of modern authority,, ${ }^{152}$ however, hold that an illegal seizure does not bar forfeiture. Their strongest argument is that the legality of the seizure has no bearing on the forfeit status of the property. ${ }^{163}$ If the property should not have been seized, it will be returned; if it should have been seized, the owner suffers nothing from which he would have been protected by a warrant. In addition, a rule calling for the return of illegally seized property might serve no function but delay because in itself it does not prevent reseizure: ${ }^{154}$ the government need only return the property, obtain a warrant, and reseize. ${ }^{165}$ A flat rule forbidding reseizure consistently would deprive the government of property to which it is entitled by statute. ${ }^{156}$

That deprivation, however, is justified where the government's conduct falls short of fourth amendment standards. ${ }^{157}$ If forfeiture

151 Taylor v. United States, 44 U.S. (3 How.) 197, 205 (1845) (anyone can make, in any manner, a forfeiture seizure at his own peril; if the government adopts the seizure and the property is forfeited, the seizer is vindicated); Wood v. United States, 41 U.S. (16 Pet.) 342, 359 (1842) (government can adopt an illegal seizure and proceed with the forfeiture, even if grounds therefor were unknown to the seizer).

152 United States v. One 1975 Pontiac Lemans, 621 F.2d 444, 451 (1st Cir. 1980); United States v. One 1971 Harley-Davidson Motorcycle, 508 F.2d 351, 351-52 (9th Cir. 1974); United States v. Carey, 272 F.2d 492, 494 n.6 (5th Cir. 1959); United States v. One 1956 Ford Tudor Sedan, 253 F.2d 725, 727 (4th Cir. 1958); United States v. Eight Boxes Containing Various Articles of Miscellaneous Merchandise, 105 F.2d 896, 899-900 (2d Cir. 1939); Mayo v. United States, 413 F. Supp. 160, 162 (E.D. Ill. 1976); United States v. One 1973 Volvo, 377 F. Supp. 810, 812 (W.D. Tex. 1974); United States v. $\$ 4,171.00$ in United States Currency, 200 F. Supp. 28, 31-33 (N.D. Ill. 1961). See Annot., 8 A.L.R.3d 473, 475 (1966).

${ }_{163}$ United States v. One 1975 Pontiac Lemans, 621 F.2d 444, 451 (1st Cir. 1980) ("there is simply no connection here between the warrantless seizure and the government's latermade case for possession").

16t United States v. One 1971 Harley-Davidson Motorcycle, 508 F.2d 351, 352 (9th Cir. 1974); United States v. Eight Boxes Containing Various Articles of Miscellaneous Merchandise, 105 F.2d 896, 900 (2d Cir. 1939).

${ }^{185}$ The property of course would remain tainted for evidentiary purposes. Unless a warrant for a subsequent search and seizure is based on independent, "untainted" evidence, the government cannot simply return the property and redo the procedure properly. E.g., Silverthorne Lumber Co. v. United States, 251 U.S. 385, 391-92 (1920).

${ }^{158}$ An illegal seizure defense would be used only in those cases in which there was probable cause for seizure and forfeiture, because the absence of probable cause could itself be pleaded as a defense to the forfeiture.

${ }^{157}$ See Dutile, supra note 127, at 20-25. See also Fed. R. CRIM. P. 41(e):

A person aggrieved by an unlawful search and seizure may move the district court for the district in which the property was seized for the return of the property on the ground that he is entitled to lawful possession of the property which was illegally seized. . . . If the motion is granted the property shall be restored and it shall not be admissible in evidence at any hearing or trial.

This rule reflects a legislative judgment that the legality of the seizure bears on the government's possessory right. Although the rule does not apply to forfeitures, where the individ- 
may proceed despite a warrantless seizure, there is little incentive to obtain a warrant in the first place. Analogy to the exclusionary rule, grounded on a similar rationale of deterring illegal government conduct, supports an absolute bar to forfeiture. ${ }^{168}$ Such an extension of the exclusionary rule could be objected to on the ground that, unlike the use of illegally seized evidence, the forfeiture of illegally seized property is not an exacerbation of a constitutional injury. Whereas use of illegally seized evidence relies on illegal conduct in a continuing manner to the detriment of the defendant, the harm in the forfeiture context arguably comes entirely from the seizure itself and is not made worse by proceeding with the forfeiture. ${ }^{160}$

Proceeding with forfeiture despite an illegal seizure could be supported by analogy to the law of arrests. An illegal arrest does not bar prosecution, even though such a rule would serve the same deterrent purposes as the exclusionary rule. ${ }^{160}$ The cost of error is too high, and the illegality of the arrest has no bearing on the government's case for conviction, which may be made by untainted evidence. ${ }^{181}$ Applying this reasoning to forfeitures, it can be argued

ual's rights of "lawful possession" are in question, the concept is analogous.

${ }^{138}$ See United States v. Plymouth Coupe, 182 F.2d 180, 182 (3d Cir. 1950) (rule that forfeiture cannot follow an illegal seizure "fits in well" with exclusionary rule), overruled on other grounds, United States v. $\$ 1,058.00$ in United States Currency, 323 F.2d 211 (3d Cir. 1963).

${ }^{159}$ See Dodge v. United States, 272 U.S. 530, 532 (1926) ("The exclusion of evidence obtained by an unlawful search and seizure stand [sic] on a different ground [from the forfeiture of property seized by unauthorized local agents]. If the search and seizure are unlawful as invading personal rights secured by the Constitution those rights would be infringed yet further if the evidence were allowed to be used."). But see Berkowitz v. United States, 340 F.2d 168, 173 (1st Cir. 1965) (arguing that forfeiture is such a further infringement); text and notes at notes $169-171$ infra.

${ }^{100}$ A recent restatement of that rule makes perfect sense if the "accused" is the property in a forfeiture proceeding:

The exclusionary principle of Wong Sun and Silverthorne Lumber Co. delimits what proof the Government may offer against the accused at trial, closing the courtroom door to evidence secured by official lawlessness. Respondent is not himself a suppressible "fruit," and the illegality of his detention cannot deprive the Government of the opportunity to prove his guilt through the introduction of evidence wholly untainted by the police misconduct.

United States v. Crews, 445 U.S. 463, 474 (1980).

161 See, e.g., United States v. Blue, 384 U.S. 251, 255 (1966):

Our numerous precedents ordering the exclusion of such illegally obtained evidence assume implicitly that the remedy does not extend to barring the prosecution altogether. So drastic a step might advance marginally some of the ends served by exclusionary rules, but it would also increase to an intolerable degree interference with the public interest in having the guilty brought to book. 
that sufficient deterrence is provided by the exclusionary rule, and that any added deterrence achieved by barring forfeiture is outweighed by the cost to society.

There are two flaws in this reasoning. First, the cost of barring forfeiture is slight. Rather than letting a criminal loose, the government is only deprived of a piece of property. ${ }^{162}$ Second, because the government's burden of proof is minimal in the forfeiture proceeding, the deterrent value of excluding certain evidence is far less than in the criminal context; in many cases the evidence will be unnecessary. To enhance deterrence, forfeiture of illegally seized property should be blocked altogether and reseizure prohibited.

2. Jurisdictional Issues. An illegal seizure also may prevent subsequent forfeiture by depriving the court of jurisdiction. Because forfeiture is in rem, jurisdiction is obtained by seizing the property and bringing it before the court. ${ }^{163}$ It can be argued that if the property is unlawfully seized, it is improperly before the court and that the court therefore lacks jurisdiction. ${ }^{164}$ Conversely, it could be argued that as long as the property is before the court it does not matter how it got there. ${ }^{185}$ A series of early Supreme Court cases supports the view that jurisdiction does not hinge on the legality of seizure. For example, in Dodge v. United States, ${ }^{106}$ seizure was made by city police officers, although the statute only authorized seizure by federal officers. Justice Holmes noted that however effected, the seizure successfully brought the property within the jurisdiction of the court, for "[t]he owner of the prop-

${ }^{162}$ A frequently stated purpose of civil forfeiture is to take property out of the hands of those who will use it to commit crimes. The rationale is dual: first, continued possession will permit continued criminal activity; second, forcing the criminal to reinvest in equipment decreases the profitability of the criminal enterprise. H.R. REP. No. 2751, 81st Cong., $2 \mathrm{~d}$ Sess. (1950), reprinted in [1950] U.S. Cone Cong. \& AD. News 2952; S. REP. No. 926, 76th Cong., 1st Sess. (1939). However, although the property on occasion may be used again criminally, this reflects the failure of the criminal, rather than the forfeiture, process.

${ }^{163}$ See Calero-Toledo v. Pearson Yacht Leasing Co., 416 U.S. 663, 679 (1974); The Brig Ann, 13 U.S. (9 Cranch) 289, 291 (1815). Jurisdiction is granted to the court of the district in which the seizure occurred. E.g., I.R.C. $\$ 7323($ a).

184 A line of Third Circuit cases so argued. United States v. Plymouth Coupe, 182 F.2d 180, 182 (3d Cir. 1950); Daufer-Lieberman Brewing Co. v. United States, 8 F.2d 1, 4 (3d Cir. 1925). However, the Circuit abandoned this view in United States v. $\$ 1,058.00$ in United States Currency, 323 F.2d 211, 213 (3d Cir. 1963).

${ }^{163}$ United States v. \$4,171.00 in United States Currency, 200 F. Supp. 28, 31-32 (N.D. Ill. 1961). Moore is unclear on this point. 7A J. MooRE, supra note 24, i C.11 n.5 ("If there is in fact a seizure, it may not matter that it was improperly or unlawfully made.").

168272 U.S. 530 (1926). 
erty suffers nothing that he would not have suffered if the seizure had been authorized."16z

Courts citing Dodge for the absolute proposition that an illegal seizure does not bar forfeiture ${ }^{168}$ read too much into the case. In Dodge the Court spoke in terms of the federal government's adoption of the city's seizure. It is one thing to adopt a seizure made by a state official without technical statutory authority, and quite another for the government to adopt an unconstitutional seizure by its own agents. One should question, on both technical and policy grounds, why the government should obtain the court's jurisdiction to forfeit someone's property by seizing it illegally. ${ }^{169}$ Moreover, basing jurisdiction on an illegal seizure is a continuing use of an illegal seizure to the detriment of the claimant in much the same way that use of illegally obtained evidence in a criminal proceeding is a continuing constitutional violation. Viewed in this light, Justice Holmes's assertion in Dodge that the forfeiture does not constitute a further infringement of constitutional rights ${ }^{170}$ is unconvincing. Because the seizure is the basis of the court's jurisdiction, the forfeiture proceeding amounts to a use of the illegal seizure to take the claimant's property permanently. ${ }^{171}$

${ }^{187}$ Id. at 532 . This justification is curious in that the same often could be said, for example, of the admission of improperly seized evidence.

${ }_{18 s}$ John Bacall Imports, Ltd. v. United States, 412 F.2d 586, 588 (9th Cir. 1969); United States v. One 1956 Ford Tudor Sedan, 253 F.2d 725, 727 (4th Cir. 1958) (specifically rejecting the argument that the Supreme Court cases were limited to instances of the government's adoption of seizures by nonfederal agents); United States v. Eight Boxes Containing Various Articles of Miscellaneous Merchandise, 105 F.2d 896, 898 (2d Cir. 1939). But see Berkowitz v. United States, 340 F.2d 168, 171 (1st Cir. 1965) (distinguishing Dodge on the ground that it involved a seizure made without statutory authority, as opposed to one in violation of the fourth amendment).

18" The same considerations are present in cases holding that a court lacks jurisdiction when the defendant has been induced to enter its territorial jurisdiction by deceit or trickery. See Commercial Mut. Accident Co. v. Davis, 213 U.S. 245, 256 (1909); Fitzgerald \& Mallory Constr. Co. v. Fitzgerald, 137 U.S. 98, 105 (1890) (also implying that the court would lack in rem jurisdiction if the "property had been brought into the state by means of fraudulent inducement"); Mallin v. Sunshine Kitchens, Inc., 314 So. 2d 203 (Fla. Dist. Ct. App. 1975), cert. denied, 330 So. 2d 22 (Fla. 1976). See generally Annot., 98 A.L.R.2d 551 (1964). It sometimes is held that jurisdiction is never acquired in such circumstances, Wyman v. Newhouse, 93 F.2d 313, 315 (2d Cir. 1937), cert. denied, 303 U.S. 664 (1938); alternatively, it is argued that the court acquires but should refuse to exercise jurisdiction, Buchanan v. Wilson, 254 F.2d 849, 850 (6th Cir. 1958).

170272 U.S. at 532.

${ }^{171}$ Even if this argument is accepted, it does not address whether the government may simply return the property, obtain a warrant, and reseize. Such a procedure presumably would provide jurisdiction. The fact that the initial jurisdiction was defective does not bar the government from trying again; a dismissal for lack of jurisdiction has no res judicata 
3. Derivative Versus Per Se Contraband. Per se contraband $^{172}$ is never returned to its owner, even at the conclusion of all related criminal proceedings ${ }^{173}$ and even if illegally seized. ${ }^{174}$ On the other hand, derivative contraband must be returned absent a statutory authorization for forfeiture. A rule denying return of all derivative contraband, presumably on the basis of an automatic forfeiture theory, would be "unsupported, broad and potentially unmanageable." 175

Illegally seized per se contraband is not returned for three reasons. First, return of such articles is against public policy. ${ }^{176}$ Second, the complete absence of any rights in the contraband means that the former possessor suffers no injury from the government's retention of the property. Insofar as his privacy rights may have been infringed by the search and seizure, he is protected by the exclusionary rule. Third, because per se contraband is destroyed, deterrence against illegal seizures is not reduced by allowing the government to retain such contraband.

In the case of derivative contraband, the very absence of these factors suggests that an illegal seizure should bar forfeiture. First, the public policy difficulties posed by return of a car are far less severe than those raised by the return of heroin or counterfeit money. Second, the owner still may have property rights. Finally, because the government can benefit from possession of the derivative contraband, ${ }^{177}$ requiring the return of illegally seized derivative contraband serves an important deterrent function.

\section{Conclusion}

Perhaps without realizing it, most courts in effect have adopted the same rules for forfeiture seizures as the Supreme Court has outlined for arrests: a warrant is unnecessary; an unconstitutional seizure does not bar "prosecution"; and a search may be

effect. A rule forbidding reseizure therefore must be based on the policy reasons outlined above. See text and notes at notes 157-162 supra.

172 For the distinction between derivative and per se contraband, see note 17 supra.

${ }^{173}$ See United States v. LaFalch, 565 F.2d 81, 83 (6th Cir. 1977), cert. denied, 435 U.S. 971 (1978).

174 See United States v. Trupiano, 334 U.S. 699, 710 (1948) (still that had been seized unconstitutionally inadmissible as evidence but not returned because per se contraband).

176 United States v. Farrell, 606 F.2d 1341, 1346 (D.C. Cir. 1979).

${ }_{176}$ See United States v. Jeffers, 342 U.S. 48, 53-54 (1951).

127 The government either will retain the property for its own use or sell it and keep the proceeds. E.g., 21 U.S.C. \& 881(e) (1976). 
made incident to the seizure. The debt to the arrest scheme goes unacknowledged, but the parallels are undeniable.

Conceptually, this congruence is pleasing and perhaps appropriate. It gives rise to a clearly demarcated body of seizure law ${ }^{178}$ in which the warrant requirement is far less strict than it is for searches. Such an approach may be the inevitable result of, or is at least legitimized by, the emphasis in recent years on privacy interests; this emphasis naturally leads to a concern with the intrusiveness of the search as distinct from that of the seizure.

This comment has demonstrated that such a dichotomy is misguided. In the forfeiture situation, a seizure warrant protects important property and privacy interests and guards against the evisceration of the search warrant requirement. In the absence of exigent circumstances, a seizure for forfeiture should be made only pursuant to a warrant, and a warrantless seizure should dictate the permanent return of the property.

Michael E. Herz

178 United States v. Bush, 647 F.2d 357, 369-70 (3d Cir. 1981), finds an emerging trend toward such a demarcation. 